\title{
Aplikasi Fungi Mikoriza Arbuskula (FMA) dan Pupuk Bokashi dengan Level Berbeda pada Pertumbuhan dan Produksi Biomasa Rumput Gajah (Pennisetum Purpureum)
}

Tarcisio De Jesus Guterres ${ }^{\mathrm{a}}$

${ }^{a}$ Fakultas Pertanian, Universitas Timor, Kefamenanu, TTU - NTT, Indonesia.

\section{Article Info}

\section{Article history:}

Received 25 November 2017

Received in revised form 23 Desember 2017 Accepted 5 Januari 2018

DOI:

https://doi.org/10.32938/ja.v3i1.539

Keywords:

Rumput Gajah

Mikoriza Arbuskula

Bokashi

\begin{abstract}
Abstrak
Penelitian ini dilaksanakan pada kebun percobaan Fakultas Pertanian, Universitas Timor, Kelurahan Sasi, Kecamatan Kota Kefamenanu, Kabupaten Timor Tengah Utara pada bulan Juli sampai Oktober 2017, dengan tujuan untuk mengetahui respon pertumbuhan dan produksi biomassa rumput gajah yang di beri Fungi Mikoriza Arbuskula dan pupuk bokashi dengan level berbeda. Rancangan penelitian yang digunakan adalah rancangan acak lengkap pola faktorial 3 x 3 yang diulang sebanyak 4 kali. Faktor pertama adalah takaran Fungi Mikoriza Arbuskula, terdiri atas 3 aras yakni 0, 20, dan 40 g/pot. Faktor kedua adalah bokashi terdiri atas 3 aras yakni 0, 250, dan 500 g/pot. Hasil penelitian menunjukkan bahwa pemberian Fungi Mikoriza Arbuskula $40 \mathrm{~g}$ dan Bokashi $500 \mathrm{~g}$ dapat meningkatkan pertumbuhan dan hasil tanaman tinggi tunas produksi $\mathrm{I}=11,1 \mathrm{~cm}$ dan produksi $\mathrm{II}=18,55 \mathrm{~cm}$, jumlah daun produksi $\mathrm{I}=8,60$ helai dan produksi $\mathrm{II}=13,38$ helai, diameter tunas produksi $\mathrm{I}=1,53 \mathrm{~cm}$ dan produksi $\mathrm{II}=2,78 \mathrm{~cm}$, berat segar daun produksi $\mathrm{I}=46,55 \mathrm{~g}$ dan produksi $\mathrm{II}=54,83 \mathrm{~g}$, tertinggi dibandingkan perlakuan lainnya dan tidak ada interaksi. Disimpulkan bahwa aplikasi bokashi pada level $500 \mathrm{~g} /$ pot yang dikombinasikan dengan fungi mikoriza $40 \mathrm{~g}$ dapat meningkatkan pertumbuhan dan produksi tanaman rumput gajah lebih baik.
\end{abstract}

\section{Pendahuluan}

Rumput merupakan pakan dasar ternak ruminansia yang banyak dibutuhkan dalam penyusunan ransum. Sebagai pakan dasar rumput memegang peranan penting dalam mencapai tujuan produksi ternak sehingga perlu diperhatikan aspek kualitas dan kuantitasnya. Rumput gajah (Pennisetum pupureum) merupakan salah satu jenis rumput unggulan hasil introduksi. Rumput ini memiliki kemampuan adaptasi yang tinggi pada iklim kering selain itu juga mampu menghasilkan produksi biomassa yang tinggi, hal ini sesuai Suyirman, (2003) produksi hijauan segar berkisar 500-800 ton/ha/tahun jumlah pemotongan 7 x panen per tahun, kandungan gizi rumput gajah protein kasar 13 $14 \%$ serat kasar 30-32 \%. Nilai pakan rumput gajah dipengaruhi oleh perbandingan (rasio) jumlah daun terhadap batang dan umurnya. Kandungan nitrogen dari hasil panen yang diadakan secara teratur berkisar antara $2-4 \%$ Protein Kasar (CP; Crude Protein) selalu di atas $7 \%$ untuk varietas Taiwan, semakin tua CP semakin menurun.

Nusa Tenggara Timur merupakan wilayah yang memiliki iklim dengan kondisi kering dengan curah hujan di Nusa Tenggara Timur umumnya pada November 2015 berkisar antara 51-100 mm, Desember 2015 dan Januari 2016 berkisar antara 201-300 mm. Sementara itu sifat hujan pada November dan Desember 2015 diperkirakan sebagian besarnya normal, hal ini dapat terlihat dengan tingginya tingkat penguapan air tanah, rendahnya kelembapan dan tingginya suhu lingkungan (BPS NTT, 2015). Pada kondisi seperti ini menyebabkan tidak semua jenis rumput dapat bertahan dalam kondisi kekeringan sedangkan pada tanaman yang bertahan cenderung menghasilkan produksi biomassa yang rendah akibat kemampuan yang rendah pada tanaman dalam memanfaatkan unsur hara dan kurang efisien dalam memanfaatkan air tanah yang tersedia.

Pemupukan sering didefinisikan sebagai menambah suatu bahan ke dalam tanah sehingga dapat menambah hara, merubah keadaan fisik, dan biologi tanah. Winarni $d k k$., (2013) menyatakan bahwa tanaman yang kekurangan unsur $\mathrm{N}$ akan mengalami pertumbuhan lambat, kerdil, daun hijau menjadi kekuningan, daunnya sempit, daun-daun tua menjadi cepat menguning dan mati. Bokashi merupakan salah satu jenis pupuk yang dapat menggantikan kehadiran pupuk kimia buatan untuk meningkatkan kesuburan tanah sekaligus memperbaiki kerusakan sifat - sifat tanah akibat pemakaian pupuk anorganik (kimia) secara berlebihan. Bokashi merupakan hasil fermentasi bahan organik dari limbah pertanian (pupuk kandang, jerami, sampah, sekam serbuk gergaji) dengan menggunakan EM-4 Atikah, 2013). EM-4 (Effective Microorganisme-4) merupakan bakteri pengurai dari bahan organik yang digunakan untuk proses pembuatan bokashi, yang dapat menjaga kesuburan tanah sehingga berpeluang untuk meningkatkan dan menjaga kestabilan produksi (Ruhukail, 2011).

Salah satu upaya yang dilakukan adalah dengan penambahan agen hayati seperti pemberian Mikoriza dilakukan pada awal penanaman. Setiadi, (2003), menyebutkan bahwa Mikoriza sangat berperan dalam meningkatkan toleransi tanaman terhadap kondisi lahan kritis, yang berupa kekeringan dan banyak terdapatnya logam-logam berat. Secara tidak langsung, Mikoriza berperan dalam perbaikan struktur tanah, meningkatkan kelarutan hara dan proses pelapukan bahan induk. Sedangkan secara langsung, Mikoriza dapat meningkatkan serapan air, hara dan melindungi tanaman dari patogen akar dan unsur toksik. Mikoriza akan berkembang pada perakaran tanaman dan bersimbiosa yang saling menguntungkan dengan tanaman inang. Aldeman \& Morton (1986) menyatakan bahwa infeksi Mikoriza dapat meningkatkan pertumbuhan tanaman dan kemampuannya memanfaatkan nutrisi terutama unsur $\mathrm{P}, \mathrm{Ca}, \mathrm{N}$ $\mathrm{Cu}, \mathrm{Mn}, \mathrm{K}$ dan $\mathrm{Mg}$. Kemampuan berkembangnya Mikoriza juga dipengaruhi oleh kemampuan adaptasi antara Mikoriza dan tanaman dengan lingkungan sekitarnya. Waktu penambahan Mikoriza menentukan kemampuan adaptasi Mikoriza dengan tanaman dan lingkungan tumbuh tanaman tersebut, yang akan menentukan kemampuan Mikoriza tersebut menjadi agen hayati pelarut fosfat yang berperan dalam pertumbuhan dan produksi tanaman rumput gajah.

\section{Metode}

Penelitian ini telah dilaksanakan pada kebun percobaan Fakultas Pertanian, Universitas Timor, Kelurahan Sasi, Kecamatan Kota Kefamenanu, Kabupaten Timor Tengah Utara pada bulan Juli sampai Oktober 2017. Alat yang digunakan adalah : pot plastik kapasitas $5 \mathrm{~kg}$ sebanyak 36 buah, pengayak tanah, peralatan bercocok tanam, mistar, timbangan analitik, gelas ukur, jangka sorong, oven, termometer dan gunting. Sedangkan bahannya adalah stekan rumput gajah, pupuk bokashi sebanyak 9 kg, Fungi Micoriza Arbuscula (FMA) sebanyak 0,72 $\mathrm{kg}$, tanah jenis Inceptisol yang telah diayak sebanyak $180 \mathrm{~kg}$, amplop, rak tanaman 4 buah dan kawat striming $6 \mathrm{~m}$. Penelitian ini menggunakan metode experiment dengan melakukan pengukuran langsung pada tanaman rumput gajah (Pennisetum purpureum). Rancangan yang digunakan dalam penelitian ini adalah rancangan acak lengkap (RAL) pola faktorial $3 \times 3 \times 4$, di mana faktor pertama adalah level Fungi Micoriza Arbuscula (FMA) terdiri dari tiga taraf meliputi:

$\mathrm{F}_{0}=$ Tanpa Fungi Micoriza Arbuscula kontrol)

$\mathrm{F}_{1}=$ Fungi Micoriza Arbuscula $20 \mathrm{~g} / \mathrm{pot}$

$\mathrm{F}_{2}=$ Fungi Micoriza Arbuscula $40 \mathrm{~g} / \mathrm{pot}$

Faktor kedua level pupuk Bokashi terdiri dari tiga taraf yaitu:

$\mathrm{B}_{0}=$ Tanpa pupuk Bokashi (kontrol)

$\mathrm{B}_{1}=$ Pupuk Bokashi $250 \mathrm{~g} / \mathrm{pot}$

$\mathrm{B}_{2}=$ Pupuk Bokashi $500 \mathrm{~g} / \mathrm{pot}$

Dari kedua faktor di atas dihasilkan 9 kombinasi perlakuan yang terdiri dari $\mathrm{F}_{0} \mathrm{~B}_{0}, \mathrm{~F}_{0} \mathrm{~B}_{1}, \mathrm{~F}_{0} \mathrm{~B}_{2}, \mathrm{~F}_{1} \mathrm{~B}_{0}, \mathrm{~F}_{1} \mathrm{~B}_{1}, \mathrm{~F}_{1} \mathrm{~B}_{2}, \mathrm{~F}_{2} \mathrm{~B}_{0}, \mathrm{~F}_{2} \mathrm{~B}_{1}, \mathrm{~F}_{2} \mathrm{~B}_{2}$

Tanah ditimbang seberat $5 \mathrm{~kg}$ kemudian dicampur dengan setiap jenis dosis pupuk bokashi sesuai dengan perlakuan yang telah disusun. Pencampuran dilakukan secara manual dengan mengaduk antara tanah dan pupuk bokashi sampai terlihat homogen. Tanah yang telah dicampurkan dengan dan pupuk bokashi diisi di dalam pot yang telah disiapkan kemudian media tanam disiram dengan air sebanyak 2 liter lalu didiamkan selama dua minggu. Dilanjutkan dengan penanaman rumput menggunakan stek rumput gajah. Penanaman dilakukan dengan melubangi media tanam dengan kedalaman $\pm 15 \mathrm{~cm}$ Selanjutnya lubang di isi dengan Fungi Mikoriza Arbuskula (FMA) ke setiap lubang tanam sesuai dengan dosis yang perlakuan, kemudian di tanam rumput gajah sebanyak 2 stek.

Pengambilan data tinggi tunas, diameter tunas dan jumlah helai daun dilakukan setiap 15 HST, 30 HST, 45 HST, 60 HST, 75 HST dan 90 HST. Sedangkan berat segar daun, berat kering daun dan kadar air dilakukan pada akhir masa produksi I (45 HST) dan produksi II (90 HST). Berat segar akar dan berat kering akar diperoleh pada saat akhir masa produksi II (90 HST). Adapun variabel yang dilihat adalah tinggi tunas, diameter tunas, jumlah helai daun, berat segar dan berat kering daun, berat segar akar dan berat kering akar serta kadar air. Data yang diperoleh dianalisis menggunakan analisis sidik ragam (Anova) dan diuji dengan menggunakan Duncan Multiple Range Test (DMRT) dengan tingkat signifikasi 5\% sesuai petunjuk Gomez \& Gomez, (1995).

\section{Hasil dan Pembahasan}

\subsection{Tinggi Tunas Masa Produksi I dan II (cm)}

Tinggi tunas merupakan salah satu kriteria dalam mengetahui laju pertumbuhan tanaman. Tinggi tunas hasil penelitian pada masa produksi I dan II dapat dilihat pada Gambar 1. Hasil analisis menunjukkan bahwa tidak terjadi interaksi antara perlakuan Fungi Micoriza Arbuskula dan pupuk bokashi terhadap pertumbuhan tinggi tunas rumput gajah masa produksi I dan produksi II. Gambar 1. menunjukkan bahwa pada perlakuan level Fungi Micoriza Arbuskula (F) dan level Bokashi (B) memperlihatkan bahwa tinggi tanaman terbaik pada masa produksi I dan masa produksi II ditunjukkan pada tanaman yang mendapat perlakuan $\mathrm{F}_{2} \mathrm{~B}_{2}$ dibandingkan $\mathrm{F}_{0} \mathrm{~B}_{0}, \mathrm{~F}_{0} \mathrm{~B}_{1}, \mathrm{~F}_{0} \mathrm{~B}_{2}, \mathrm{~F}_{1} \mathrm{~B}_{0}, \mathrm{~F}_{1} \mathrm{~B}_{1}, \mathrm{~F}_{1} \mathrm{~B}_{2}$ $\mathrm{F}_{2} \mathrm{~B}_{0}$ dan $\mathrm{F}_{2} \mathrm{~B}_{1}$. Tinggi tunas masa produksi I dan II lebih dipengaruhi oleh faktor level bokashi karena kandungan yang tersedia di dalam pupuk bokashi yaitu 
kandungan $\mathrm{N}(23,09136), \mathrm{P}(7,32336)$ dan $\mathrm{K}(26,38512)$ yang sangat tinggi oleh sebab itu pupuk bokashi sangat berperan aktif dalam pertumbuhan.

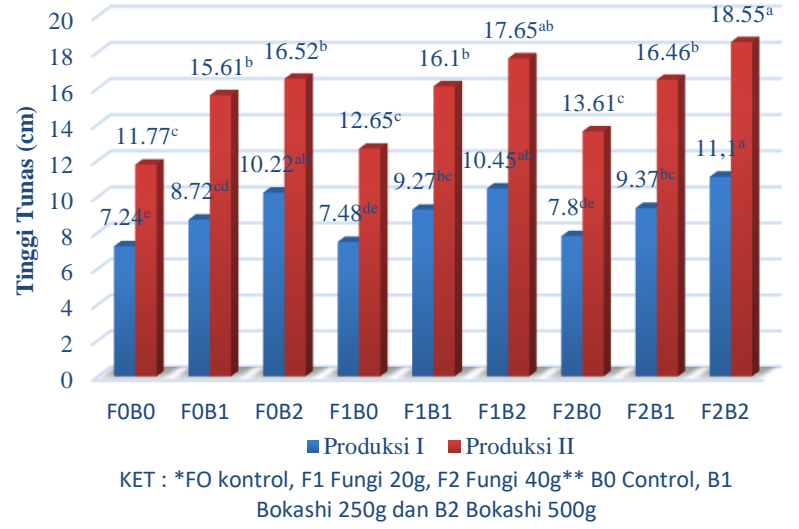

Gambar 1. Tinggi Tunas Masa Produksi I dan II

\subsection{Diameter Tunas Masa Produksi I dan II (cm)}

Diameter tunas merupakan salah satu kriteria dalam mengetahui laju pertumbuhan tanaman. Hasil analisis sidik ragam menunjukkan bahwa tidak terjadi interaksi antara perlakuan Fungi Micoriza Arbuskula dan Bokashi terhadap pertumbuhan diameter tunas rumput gajah masa produksi I dan produksi II. Gambar 2 menunjukkan bahwa pada perlakuan level Fungi Micoriza Arbuskula (F) dan level bokashi (B) memperlihatkan bahwa diameter tunas terbaik pada masa produksi I dan masa produksi II ditunjukkan pada tanaman yang mendapat perlakuan $\mathrm{F}_{2} \mathrm{~B}_{2}$ dibandingkan $\mathrm{F}_{0} \mathrm{~B}_{0}, \mathrm{~F}_{0} \mathrm{~B}_{1}, \mathrm{~F}_{0} \mathrm{~B}_{2}, \mathrm{~F}_{1} \mathrm{~B}_{0}, \mathrm{~F}_{1} \mathrm{~B}_{1}, \mathrm{~F}_{1} \mathrm{~B}_{2}$ $\mathrm{F}_{2} \mathrm{~B}_{0}$ dan $\mathrm{F}_{2} \mathrm{~B}_{1}$. Diameter tunas pada rumput gajah lebih dipengaruhi oleh faktor level Bokashi karena kandungan yang tersedia di dalam pupuk bokashi yaitu kandungan $N$ 23,09136), $P(7,32336)$ dan $K(26,38512)$ yang sangat tinggi oleh sebab itu pupuk bokashi sangat berperan aktif dalam pertumbuhan. Hal ini sependapat dengan Nasir (2008), bahwa pupuk organik bokashi mengandung unsur $\mathrm{N}, \mathrm{P}$ dan $\mathrm{K}$ dan unsur mikro seperti ca, $\mathrm{Mg}, \mathrm{B}$ dan $\mathrm{S}$ dan lain-lain serta dapat menetralkan $\mathrm{pH}$ tanah. Diameter tunas hasil penelitian pada masa produksi I dan II dapat dilihat pada Gambar 2.

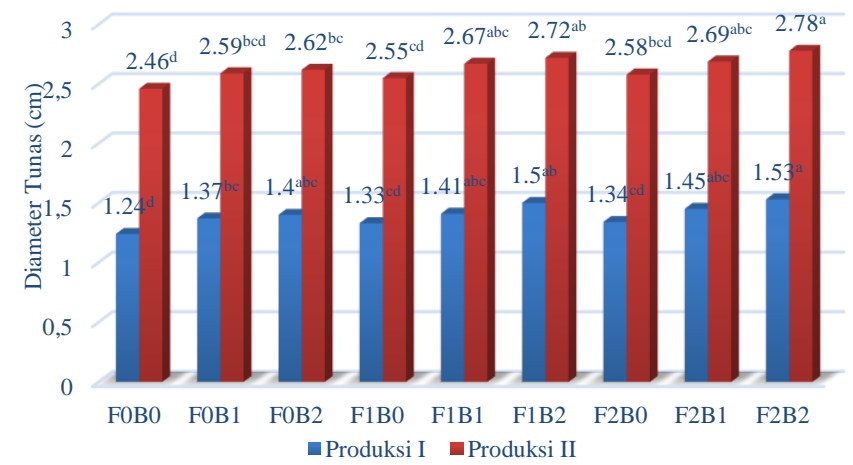

KET : *FO kontrol, F1 Fungi 20g, F2 Fungi 40g** B0 Control, B1 Bokashi 250g dan B2 Bokashi 500g

Gambar 2. Diameter Tunas Masa Produksi I dan II

\subsection{Jumlah Daun Masa Produksi I dan II (Helai)}

Jumlah daun merupakan salah satu kriteria dalam mengetahui laju pertumbuhan tanaman dengan bertambahnya jumlah daun pada tanaman. Hasil analisis sidik ragam menunjukkan bahwa tidak terjadi interaksi antara perlakuan Fungi Micoriza Arbuskula dan bokashi terhadap pertumbuhan jumlah daun rumput gajah masa produksi I dan produksi II. Dari Gambar 3 menunjukkan bahwa pada perlakuan level Fungi Micoriza Arbuskula (F) dan level bokashi (B) memperlihatkan bahwa jumlah daun terbaik pada masa produksi I dan masa produksi II ditunjukkan pada tanaman yang mendapat perlakuan $\mathrm{F}_{2} \mathrm{~B}_{2}$ dibandingkan $\mathrm{F}_{0} \mathrm{~B}_{0}, \mathrm{~F}_{0} \mathrm{~B}_{1}, \mathrm{~F}_{0} \mathrm{~B}_{2}, \mathrm{~F}_{1} \mathrm{~B}_{0}, \mathrm{~F}_{1} \mathrm{~B}_{1}, \mathrm{~F}_{1} \mathrm{~B}_{2}, \mathrm{~F}_{2} \mathrm{~B}_{0}$ dan $\mathrm{F}_{2} \mathrm{~B}_{1}$. Peningkatan jumlah daun pada rumput gajah lebih disebabkan faktor level Bokashi karena kandungan yang tersedia di dalam pupuk bokashi yaitu kandungan $\mathrm{N}(23,09136)$, $\mathrm{P}(7,32336)$ dan $\mathrm{K}(26,38512)$ yang sangat tinggi oleh sebab itu pupuk bokashi sangat berperan aktif dalam pertumbuhan. Sedangkan pada faktor level Fungi Mikoriza Arbuskula tidak memberikan pengaruh yang nyata. Jumlah daun hasil penelitian pada masa produksi I dan II dapat dilihat pada Gambar 3.

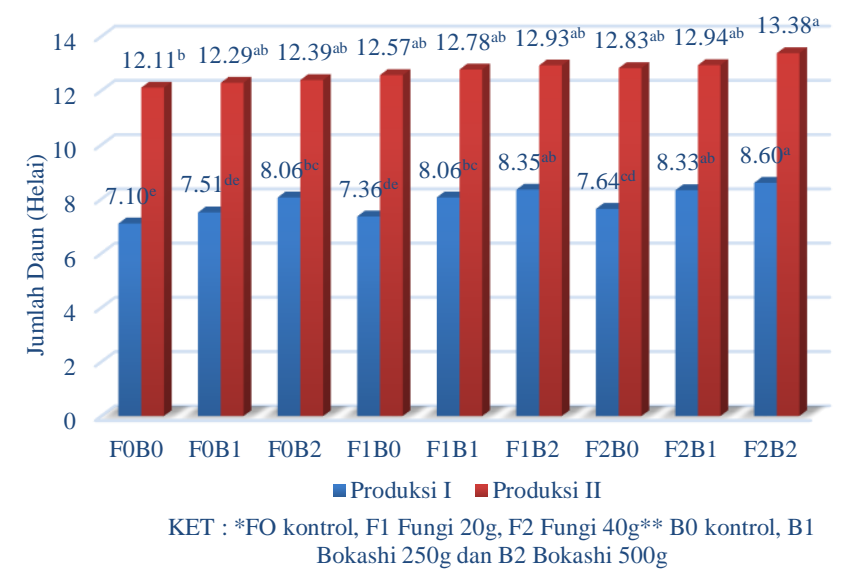

Gambar 3. Jumlah Daun Masa Produksi I dan II

\subsection{Berat Segar Daun Masa Produksi I dan II (g)}

Berat segar daun merupakan salah satu parameter yang dapat mewakili pertumbuhan tanaman. Semakin besar berat segar daun berarti semakin banyak biomassa yang dihasilkan, dalam hal ini tentunya berkaitan dengan jumlah unsur hara yang tersedia di tanah. Hasil analisis sidik ragam menunjukkan bahwa tidak terjadi interaksi antara perlakuan Fungi Micoriza Arbuskula dan bokashi terhadap bobot segar daun produksi I dan produksi II. Dari Gambar 4 menunjukkan bahwa pada perlakuan level Fungi Micoriza Arbuskula (F) dan level bokashi (B) memperlihatkan bahwa bobot segar daun terbaik pada masa produksi I dan masa produksi II ditunjukkan pada tanaman yang mendapat perlakuan $\mathrm{F}_{2} \mathrm{~B}_{2}$ dibandingkan $\mathrm{F}_{0} \mathrm{~B}_{0}, \mathrm{~F}_{0} \mathrm{~B}_{1}, \mathrm{~F}_{0} \mathrm{~B}_{2}, \mathrm{~F}_{1} \mathrm{~B}_{0}, \mathrm{~F}_{1} \mathrm{~B}_{1}, \mathrm{~F}_{1} \mathrm{~B}_{2}, \mathrm{~F}_{2} \mathrm{~B}_{0}$ dan $\mathrm{F}_{2} \mathrm{~B}_{1}$ Hasil ini menunjukkan peningkatan level Fungi Mikoriza Arbuskula yang diikuti bokashi N (23,09136), P $(7,32336)$ dan K $(26,38512)$ secara umum mampu menghasilkan nilai berat segar daun lebih baik. Berat daun hasil penelitian pada masa produksi I dan II dapat dilihat pada Gambar 4.

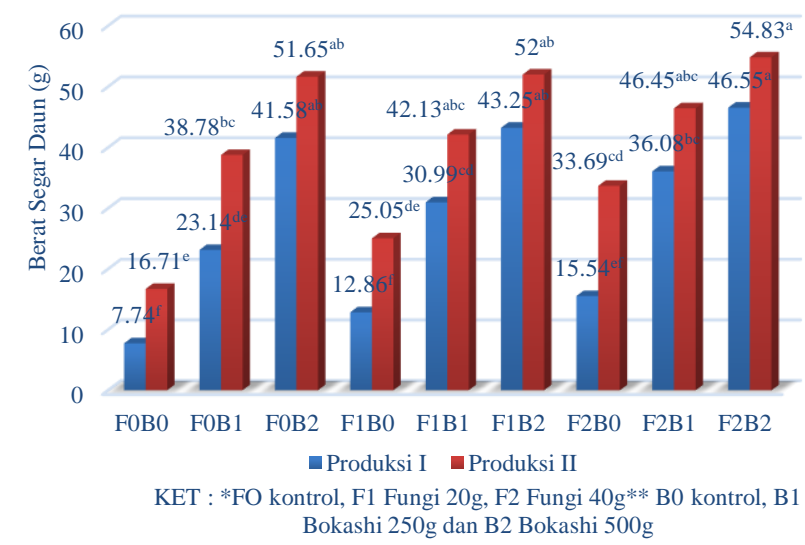

Gambar 4. Berat Segar Daun Masa Produksi I dan II

\subsection{Berat Kering Daun Masa Produksi I dan II (g)}

Berat kering daun merupakan salah satu kriteria dalam mengetahui laju pertumbuhan tanaman dengan bertambahnya berat kering daun pada tanaman Hasil analisis sidik ragam menunjukkan bahwa tidak terjadi interaksi antara perlakuan Fungi Micoriza Arbuskula dan bokashi terhadap bobot kering daun produksi I dan produksi II. Gambar 5 menunjukkan bahwa pada perlakuan level Fungi Micoriza Arbuskula (F) dan level bokashi (B) memperlihatkan bahwa berat kering daun terbaik pada masa produksi I dan masa produksi II ditunjukkan pada tanaman yang mendapat perlakuan $\mathrm{F}_{2} \mathrm{~B}_{2}$ dibandingkan $\mathrm{F}_{0} \mathrm{~B}_{0}, \mathrm{~F}_{0} \mathrm{~B}_{1}, \mathrm{~F}_{0} \mathrm{~B}_{2}, \mathrm{~F}_{1} \mathrm{~B}_{0}$ $\mathrm{F}_{1} \mathrm{~B}_{1}, \mathrm{~F}_{1} \mathrm{~B}_{2}, \mathrm{~F}_{2} \mathrm{~B}_{0}$ dan $\mathrm{F}_{2} \mathrm{~B}_{1}$. Hasil ini menunjukkan peningkatan level Fungi Mikoriza Arbuskula yang diikuti bokashi N $(23,09136)$, P $(7,32336)$ dan K $(26,38512)$ secara umum mampu menghasilkan nilai berat kering daun lebih baik. Berat daun hasil penelitian pada masa produksi I dan II dapat dilihat pada Gambar 5.

\subsection{Berat Segar dan Kering Akar (g)}

Berat segar dan berat kering akar merupakan salah satu kriteria dalam mengetahui laju pertumbuhan tanaman. Hasil analisis sidik ragam menunjukkan bahwa tidak terjadi interaksi antara perlakuan Fungi Micoriza Arbuskula dan bokashi terhadap bobot segar akar dan bobot kering akar. Gambar 6 menunjukkan bahwa pada perlakuan level Fungi Micoriza Arbuskula (F) dan level bokashi (B) memperlihatkan bahwa bobot segar akar dan bobot kering akar ditunjukkan pada tanaman yang mendapat perlakuan $\mathrm{F}_{2} \mathrm{~B}_{2}$ dibandingkan $\mathrm{F}_{0} \mathrm{~B}_{0}$ 
$\mathrm{F}_{0} \mathrm{~B}_{1}, \mathrm{~F}_{0} \mathrm{~B}_{2}, \mathrm{~F}_{1} \mathrm{~B}_{0}, \mathrm{~F}_{1} \mathrm{~B}_{1}, \mathrm{~F}_{1} \mathrm{~B}_{2}, \mathrm{~F}_{2} \mathrm{~B}_{0}$ dan $\mathrm{F}_{2} \mathrm{~B}_{1}$. Hasil ini menunjukkan peningkatan level Fungi Mikoriza Arbuskula yang diikuti bokashi N (23,09136), P (7,32336) dan $\mathrm{K}(26,38512)$ secara umum mampu menghasilkan nilai berat segar akar dan berat kering akar lebih baik. Berat segar dan kering akar hasil penelitian dapat dilihat pada Gambar 6 .

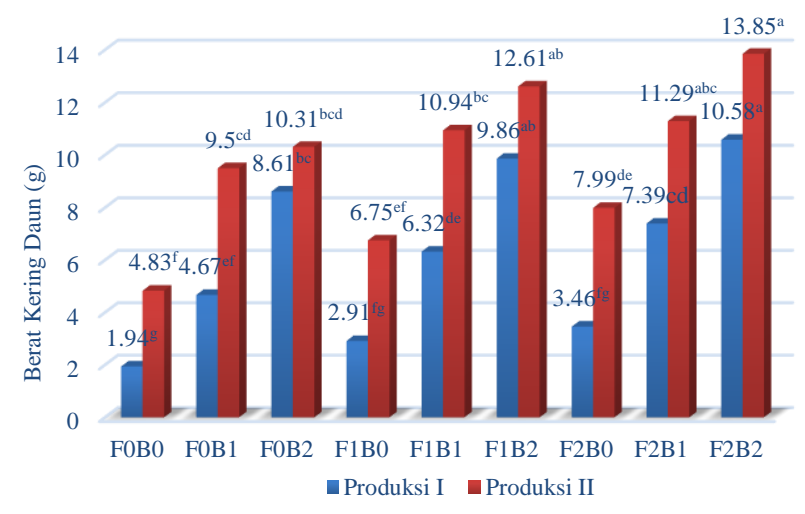

KET : *FO kontrol, F1 Fungi 20g, F2 Fungi 40g** B0 kontrol, B1 Bokashi 250g dan B2 Bokashi 500g

Gambar 5. Berat Kering Daun Masa Produksi I dan II

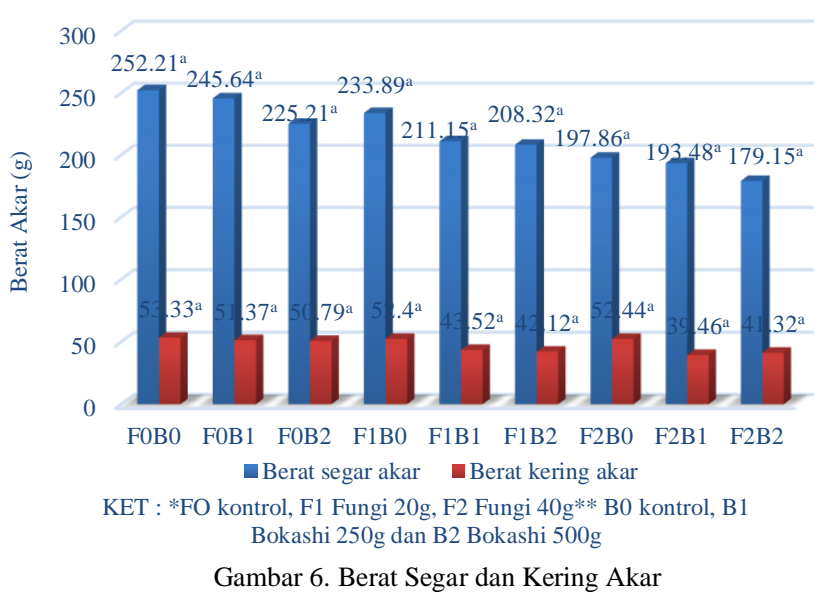

3.7 Kadar Air (\%)

Kadar air merupakan salah satu kriteria dalam mengetahui laju pertumbuhan tanaman dengan bertambahnya kadar air pada tanaman. Hasil analisis sidik ragam menunjukkan tidak terjadi interaksi antara pemberian Fungi Micoriza Arbuskula dan bokashi terhadap kadar air. Gambar 7 menunjukkan bahwa pada perlakuan level Fungi Micoriza Arbuskula (F) dan level bokashi (B) memperlihatkan bahwa kadar terbaik pada masa produksi pertama dan masa produksi kedua ditunjukkan pada tanaman yang mendapat perlakuan $\mathrm{F}_{2} \mathrm{~B}_{2}$ dibandingkan $\mathrm{F}_{0} \mathrm{~B}_{0}, \mathrm{~F}_{0} \mathrm{~B}_{1}, \mathrm{~F}_{0} \mathrm{~B}_{2}, \mathrm{~F}_{1} \mathrm{~B}_{0}, \mathrm{~F}_{1} \mathrm{~B}_{1}, \mathrm{~F}_{1} \mathrm{~B}_{2}, \mathrm{~F}_{2} \mathrm{~B}_{0}$ dan $\mathrm{F}_{2} \mathrm{~B}_{1}$. Hasil ini menunjukkan peningkatan level Fungi Micoriza Arbuskula yang diikuti bokashi $\mathrm{N}(23,09136), \mathrm{P}(7,32336)$ dan K (26,38512) secara umum mampu menghasilkan nilai kadar lebih baik. Kadar air hasil pengukuran dapat dilihat pada Gambar 7.

Pada hasil pengamatan pada variabel pertumbuhan yang meliputi tinggi tunas, diameter tunas, jumlah helai daun menunjukkan bahwa tidak terdapat interaksi antara level Fungi Mikoriza Arbuskula dan bokashi. Secara umum komponen pertumbuhan pada rumput gajah lebih disebabkan karena pengaruh level bokashi N $(23,09136), \mathrm{P}(7,32336)$ dan K $(26,38512)$ sedangkan pada level Fungi Mikoriza Arbuskula tidak memberikan kontribusi secara signifikan terhadap nilai pertumbuhan tanaman. Sedangkan pada variabel produksi meliputi berat segar daun dan berat kering daun sangat juga dipengaruhi oleh level bokashi namun pada berat segar akar, berat kering akar dan kadar air pada faktor level Fungi Mikoriza Arbuskula dan bokashi tidak memberikan pengaruh yang signifikan.

Nilai tertinggi pertumbuhan dan produksi rumput gajah pada level bokashi 500g/pot yang dikombinasikan dengan Fungi Mikoriza Arbuskula 40g/pot dimasa produksi I dan II menghasilkan tinggi tunas, diameter tunas dan jumlah daun baik lebih tinggi dibandingkan level bokashi $250 \mathrm{~g} /$ pot dan kontrol. Pada tanaman tinggi tunas produksi $\mathrm{I}=11,1 \mathrm{~cm}$ dan produksi $\mathrm{II}=18,55 \mathrm{~cm}$, jumlah daun produksi $\mathrm{I}=8,60$ helai dan produksi II $=13,38$ helai, diameter tunas produksi $\mathrm{I}=1,53 \mathrm{~cm}$ dan produksi $\mathrm{II}=2,78 \mathrm{~cm}$, berat segar daun produksi $\mathrm{I}=$ $46,55 \mathrm{~g}$ dan produksi $\mathrm{II}=54,83 \mathrm{~g}$, Tingginya nilai pertumbuhan dan produksi pada rumput gajah dalam penelitian ini disebabkan karena tersedianya nutrisi bagi tanaman dalam bentuk unsur hara makro seperti Nitrogen $(\mathrm{N})$, fosfor $(\mathrm{P})$ dan Kalium (K) dalam jumlah yang memadai dari kontribusi pemberian bokashi, di mana hasil analisis laboratorium menunjukkan bahwa ketersediaan $\mathrm{N}$ $(23,09136), \quad P(7,32336)$ dan $\mathrm{K}(26,38512)$ sangat menunjang dalam menyediakan hara pada tanah dan membantu menetralkan $\mathrm{pH}$ tanah yang asam. Hal ini sesuai pendapat Gabesius (2012) yang mengatakan bahwa bokashi dapat digunakan untuk meningkatkan kesuburan tanah melalui perbaikan sifat fisik, kimia, dan biologi tanah. Pengaruh terhadap sifat fisik tanah yaitu melalui pembentukan agregat tanah sehingga dapat memperbaiki struktur tanah. Pengaruh terhadap sifat kimia tanah adalah meningkatnya kandungan unsur hara tanah, sedangkan pengaruhnya terhadap biologi tanah adalah meningkatnya populasi dan aktivitas mikroorganisme sehingga ketersediaan unsur hara akan meningkat pula.

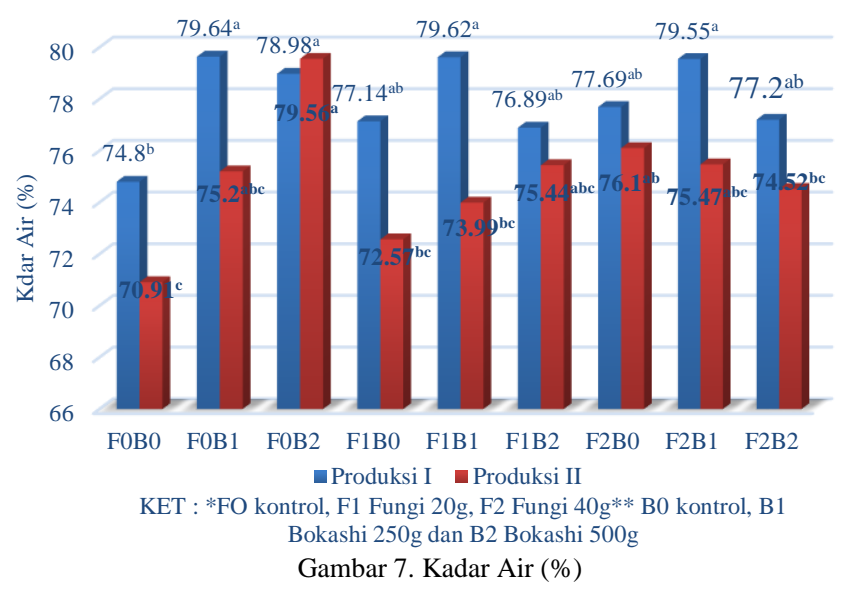

\section{Simpulan}

Disimpulkan bahwa tidak terjadi interaksi antara perlakuan Fungi Mikoriza Arbuskula (FMA) dan pupuk bokashi. Fungi Mikoriza Arbuskula (FMA) tidak berpengaruh terhadap pertumbuhan

\section{Pustaka}

Aldeman, J.M., and J.B. Morton. 1986. Invektivity of vesicular - arbuscular mycorrhizal fungi influence host soil diluents combination on MPN estimates and percentage colonization. Soil Biol-chen. 8(1):77-83.

Atikah T. A. 2013. Pertumbuhan dan hasil tanaman terung ungu varietas Yumi F1 dengan pemberian berbagai bahan organik dan lama inkubasi pada tanah berpasir. Anterior Jurnal 12(2):6-12.

BPS. 2015. Nusa Tenggara Timur Dalam Angka. Curah hujan di Nusa Tenggara Timur.

Gabesius Y. O. , L. A. M. Siregar dan Y. Husni. 2012. Respon pertumbuhan dan produksi beberapa varietas kedelai $($ Glycine $\max (\mathrm{L})$ Merrill) terhadap pemberian pupuk bokashi. Jurnal Online Agroteknologi, 1(1):220-236.

Gomez K. A. dan Gomez A. A. 1995. Prosedur Statistik Untuk Penelitian Pertanian. Edisi ke 2. UI Press : Jakarta.

Nasir. 2008. Pengaruh Penggunaan Pupuk Bokashi Pada Pertumbuhan Dan Produksi Padi Palawija Dan Sayuran. http://www.dispertanak.pandeglang.-go.id. Diakses tanggal 9 Februari 2017.

Ruhukail N. L. 2011. Pengaruh penggunaan EM4 yang dikulturkan pada bokashi dan pupuk anorganik terhadap produksi kacang tanah (Arachis hypogaea L). Jurnal Agroforestri, 4(2): 114-150.

Setiadi Y. 2003. Arbuscular mycorrhizal inokulum produktion. Program dan Abstrak Seminar dan Pameran : Teknologi Produksi dan Pemanfaatan Inokulan Endo-Ektomikoriza untuk Pertanian, Perkebunan dan Kehutanan. 16 September 2003. Bandung. pp 10.

Suyirman 2003. Agrostologi. Universitas Andalas press. hal. 54-55

Winarni E., R. D. Ratnani dan I. Riwayati. 2013. Pengaruh Jenis Pupuk Organik Terhadap Pertumbuhan Tanaman Kopi. Momentum. Vol. 9. No. 1. Hal. 35-39. 